\title{
Differential Involvement of Protein Kinase C Isozymes in Alzheimer's Disease
}

\author{
Eliezer Masliah, Gregory Cole, Shun Shimohama, ${ }^{a}$ Lawrence Hansen, Richard DeTeresa, Robert D. Terry, and \\ Tsunao Saitoh \\ Department of Neurosciences, School of Medicine, and Center for Molecular Genetics, University of California, San \\ Diego, La Jolla, California 92093
}

\begin{abstract}
Decreased levels of protein kinase $C$ (PKC) and a reduction in the in vitro phosphorylation of a $M, 86,000$ protein (P86), the major PKC substrate, are biochemical characteristics of brain tissue from patients with Alzheimer's disease (AD) (Cole et al., 1988). In the current study, we utilized antibodies against individual isozymes of PKC to assess the degree of involvement of different PKC isoforms in $A D$. The concentration of PKC $(\beta I I)$ was lower in particulate fractions prepared from $A D$ hippocampal and cortlcal tissue than in controls and higher in AD cytosol fractions from the cortex than in controls. Immunohistochemical studies in AD neocortex revealed reduced numbers of anti-PKC $(\beta I I)$-immunopositive neurons and diminished staining intensity. In contrast, $A D$ hippocampal neurons in CA3-CA4 were more intensely stained with anti-PKC $(\beta I)$ antiserum than were controls. The concentration of $\mathrm{PKC}(\beta \mathrm{I})$ was lower in particulate fractions prepared from AD hippocampus than in controls and was higher in soluble fractions prepared from $A D$ cortex than in controls. The concentration of $\operatorname{PKC}(\alpha)$ was lower in AD particulate fractions than in controls in the hippocampus. Immunohistochemistry with $\operatorname{PKC}(\alpha)$ antiserum revealed moderately intense neuron staining and an intense staining of glial cells in AD neocortex. The concentrations and histochemical distributions of $\operatorname{PKC}(\gamma)$ were not altered in the disease. PKC immunoreactivity was also found in neuritic plaques. The staining patterns of neuritic plaques with different isoform antibodies varied considerably. Anti-PKC $(\alpha)$ faintly stained entire plaques and surrounding glial cells; anti-PKC $(\beta I)$ stained dystrophic plaque neurites; and anti$\operatorname{PKC}(\beta I)$ stained the amyloid-containing portions of plaques.
\end{abstract}

\footnotetext{
Received Aug. 25, 1989; revised Dec. 11, 1989; accepted Jan. 31, 1990.

We thank Dennis Olshefski of the peptide synthesis facility at UCSD for synthesizing peptides employed in the current study. Antibodies against ubiquitin, PHF, amyloid $\beta$-protein, and PKC were obtained from Dr. A. Haas, Dr. D. Selkoe, Dr. C. Masters, and Dr. K.-P. Huang, respectively. We gratefully acknowledge their generosity. We also thank Dr. R. Katzman for critically reading the manuscript, and R. W. Davignon for advice and assistance in preparing the manuscript. This work has been supported by grants from the McKnight Endowment Fund for Neuroscience, the Pew Charitable Trust, the California State Department of Health Services, Sandoz Foundation for Gerontological Rescarch, and the National Institutes of Health (AG05131 and AG08205). E.M. is supported by NIH Training Grant NS-07078, and G.C. is a recipient of a National Research Service Award (AG05424A)

"Dr. Shimohama's present address is the Department of Neurology, Faculty of Medicine, Kyoto University, 54 Shogoin, Kawaharacho, Sakyoku, Kyoto, 606, Japan.

Copyright (C) 1990 Society for Neuroscience $0270-6474 / 90 / 072113-12 \$ 03.00 / 0$
}

Anti-PKC $(\gamma)$ did not stain plaques. These results suggest the involvement of several PKC isoforms in different aspects of AD pathogenesis.

Activation of protein kinase C (PKC), a phospholipid- and calcium-dependent kinase, through cell surface signal-transduction mechanisms plays a crucial role in the regulation of many cellular functions, including adhesion, secretion, growth, and differentiation (reviewed by Nishizuka, 1988, 1989). PKC is distributed throughout the body but is especially abundant in the brain (Takai ct al., 1977). Scvcral groups of investigators have demonstrated different forms of the enzyme in the brain (Huang et al., 1987, 1988; Jaken and Kiley, 1987; Sekiguchi et al., 1987; Shearman et al., 1987; Woodgett and Hunter, 1987). Moreover, the use of molecular cloning techniques has revealed cDNAs for 7 PKC transcripts (Ono et al., 1988). In the CNS, PKC appears to be involved in several important specialized functions. For example, PKC activation plays a critical role in longterm potentiation (Routtenberg, 1986), and PKC seems to be involved in the survival of neurons since many neuronal trophic factors function through PKC activation (Montz et al., 1985; Hama et al., 1986).

Alzheimer's disease (AD) is a progressive neurological disorder characterized by a gradual deterioration of cognitive and memory functions (Katzman, 1986), generally associated with the neurodegeneration. Because of the importance of PKC in the maintenance of ncuronal survival, we began the study of $\mathrm{PKC}$ in $\mathrm{AD}$. In the frontal cortex of patients with $\mathrm{AD}$, the concentration of $\mathrm{PKC}$, as measured by radioactive phorbol ester binding, is reduced (Cole et al., 1988). There are several possible explanations for the reduction of $\mathrm{PKC}$ in $\mathrm{AD}$ brain. Because there is extensive neuronal loss in $\mathrm{AD}$, reduced $\mathrm{PKC}$ may merely reflect diminished numbers of neurons. Alternatively, reduced PKC may precede the neuronal degeneration, and the reduction may be involved in the process of neuronal death. The finding of reduced levels of PKC in fibroblasts derived from AD patients as compared to controls (Huynh et al., 1989) rules out the possibility that all PKC changes in AD are secondary to neuronal loss and gliosis and favors the possibility of PKC involvement in the process of cellular dysfunction or degeneration. Fibroblasts contain only the $\mathrm{PKC}(\alpha)$ isoform, whereas brain contains at least 7 PKC isoforms (Nishizuka, 1989). Analysis of PKC isoforms in $\mathrm{AD}$ brain is of interest because some of them are shown, from animal studies, to be relatively restricted to CNS tissue, and the region-specific and selective subcellular distributions of the different isoforms suggest selective neuronal func- 
tions. No such information, however, is available in human brain. In this study, we employed antibodies to 4 isoforms of PKC to study them in human brain and to further characterize PKC abnormalities in AD brain.

\section{Materials and Methods}

In all, 18 brains were studied. There were 11 cases of AD and 7 agematched normal controls. All the AD patients were clinically demented, whereas those in the control group were not. The AD subjects ranged in age from 61 to 91 years, with an average of 79 , while the controls varied from 50 to 89 and averaged 70 years of age. Among the AD patients, the final cause of death was listed as cardiovascular in 4 , pneumonia in 2, diabetes mellitus in 1, and bleeding peptic ulcers in 1. In the remaining $3 \mathrm{AD}$ cases, no diagnosis other than $\mathrm{AD}$ was given as a cause of death. Among the control cases, 3 died of widely metastatic carcinoma, 3 of cardiovascular disease, and 1 from emphysema complicated terminally by pneumonia. Six of the $11 \mathrm{AD}$ patients were receiving Haldol during their terminal institutionalization, and another was on Melaril. None of the controls was being treated with neuroleptics. The effects of this difference in drug treatment between the AD cases and the controls with reference to PKC isocnzyme immunoreactivity are unknown.

Information about exact postmortem intervals prior to brain freezing and fixation was available in all control cases (range, 3-12 hr; average, $8 \mathrm{hr}$ ), and in 8 of the AD specimens (range, 3-12 hr; average, $7 \mathrm{hr}$ ). For the remaining $3 \mathrm{AD}$ brains, such detailed information was unavailable, but no specimens were included if the postmortem interval exceeded $12 \mathrm{hr}$. Therefore, with a pessimistic assumption of $12 \mathrm{hr}$ for the $3 \mathrm{AD}$ specimens, the postmortem intervals of the entire $\mathrm{AD}$ group could not exceed a range of 3-12 hr, with an average of $8 \mathrm{hr}$. The effects of variable postmortem intervals of less than $12 \mathrm{hr}$ on $\mathrm{PKC}$ isoenzyme immunoreactivity are unlikely to be great, since the SDs of the relative PKC immunoreactivities were not excessive (see below and Figs. 2 and 3). We did not detect any changes in immunostaining intensity attributable to postmortem interval effects in the immunohistochemical portion of the study (see below and Figs. 4-8 and 10).

The control and AD brain samples were collected from the same sources over the course of several years, from 1984 to 1989 . The frozen brain tissue was kept at $-70^{\circ} \mathrm{C}$ until samples were processed for Western blot analyses. Some of the specimens from each group, then, had been frozen for up to 4 years, while others had been frozen for only a few weeks, but there was no systematic bias in storage duration between the $\mathrm{AD}$ brains and the controls. Storage duration is not likely to be a significant variable in this study in any case, since the Western blot analyses quantify antigenicity rather than activity of PKC isoenzymes. While prolonged frozen storage could reasonably be expected to affect enzyme activity due to protein denaturation, a loss of antigenicity would require actual protein degradation, which should not occur at $-70^{\circ} \mathrm{C}$.

Following removal, the brains were divided sagittally and the left hemibrain was fixed in $10 \%$ formalin while the right hemibrain was frozen at $-70^{\circ} \mathrm{C}$. Before dissection, the right hemibrains were kept for $4 \mathrm{hr}$ at $4^{\circ} \mathrm{C}$ and sections approximately $1 \mathrm{~cm}$ thick were sliced while the brains were still frozen. Midfrontal cortex and hippocampus were dissected from these sections on a glass plate cooled from below by a bed of powdered dry ice. Dissected cortex was placed in 10 volumes of the homogenization buffer $(0.32 \mathrm{~m}$ sucrose, $5 \mathrm{~mm}$ HEPES, pH $8.0,5 \mathrm{~mm}$ benzamidine, $2 \mathrm{~mm} \beta$-mercaptoethanol, $3 \mathrm{~mm}$ EGTA, $0.5 \mathrm{mM} \mathrm{MgSO}_{4}$, $10 \mu \mathrm{M}$ sodium meta vanadate, $0.1 \mathrm{mM}$ PMSF, $10 \mu \mathrm{g} / \mathrm{ml}$ leupeptin, 5 $\mu \mathrm{g} / \mathrm{ml}$ pepstatin $\mathrm{A}$, and $10 \mu \mathrm{g} / \mathrm{ml}$ aprotinin) and homogenized by two $5-\mathrm{sec}$ strokes of a Polytron homogenizer (Brinkmann, Westbury, NY). This homogenate was centrifuged $1 \mathrm{hr}$ at $100,000 \times g$ at $2^{\circ} \mathrm{C}$ to separate the cytosol from the particulate fraction. The particulate fraction was reconstituted into the original volume of the homogenization buffer. After assaying the protein concentration by the method of Lowry et al. (1951), both fractions were adjusted to $1 \mathrm{mg}$ protein $/ \mathrm{ml}$ by adding the homogenization buffer, divided into aliquots, frozen in an ethanol/dryice bath, and stored at $-70^{\circ} \mathrm{C}$ until used for Western blot analysis.

After $10-14 \mathrm{~d}$ of formalin fixation, left hemibrains were examined grossly and dissected, and blocks were taken from all cerebral lobes, hippocampus, basal ganglia, substantia innominata, hypothalamus, amygdala, mesencephalon, pons, and cerebellum. Hematoxylin and eosine (H \& E) and Nissl preparations from these areas were examined for overall neuropathologic evaluation. Thioflavine S-stained sections (8 $\mu \mathrm{m}$ thick, $1 \%$ aqueous thioflavine S) were viewed with ultraviolet illumination and fluorescein filters for the identification of neocortical neurofibrillary tangles, neuritic plaques, and vascular amyloid. Most $\mathrm{AD}$ brains had large numbers of neuritic plaques and neurofibrillary tangles in the neocortex. In some cases, only plaques were present, but they occurred in sufficient numbers to assure the diagnosis. The brains of 2 cases without clinical dementia contained small foci of old or recent infarction, but without sufficiently extensive parenchymal loss to result in clinical dementia. Six normal $(70 \pm 10 \mathrm{yr})$ and $6 \mathrm{AD}(75 \pm 5 \mathrm{yr})$ cases (postmortem interval $7 \pm 4 \mathrm{hr}$ for both normal and AD) were chosen for the detailed immunohistochemical analysis reported in this study.

Antibodies against PKC isoenzymes. Antisera were raised in rabbits against synthetic peptides predicted from the human $\mathrm{cDNA}$ sequence corresponding to the C-terminal portion of $4 \mathrm{PKC}$ isozymes, $\alpha, \beta \mathrm{I}, \beta \mathrm{II}$, and $\gamma$. The sequences used were PQFVHPILQSAV [PKC $(\alpha), 661-672]$, SYTNPEFVINV [PKC $(\beta I), 661-671]$, NSEFLKPEVKS [PKC $(\beta I I), 663-$ 673], and SPISPTVPVM [PKC $(\gamma), 687-697]$. The C-terminal cysteine was added to the peptides so that they could be conjugated to proteins by the method of Green et al. (1982). Two carrier proteins and 2 conjugation methods were used for the immunization. First, peptides were conjugated to keyhole limpet hemocyanin $(\mathrm{KLH})$ as described previously (Cole et al., 1989). Second, peptides were conjugated to rabbit serum albumin (RSA) by using glutaraldehyde. Briefly, $1.0 \mathrm{ml}$ of 20 mM glutaraldehyde was mixed with $20 \mathrm{mg} \mathrm{RSA}$ in $0.5 \mathrm{ml}$ of $0.4 \mathrm{~mm}$ phosphate, $\mathrm{pH} 7.5$, and $15 \mu \mathrm{mol}$ of synthetic peptide in $1.5 \mathrm{ml}$ of water by adding glutaraldehyde dropwise with stirring over the course of 5 min. The peptide-RSA conjugates were stirred at room temperature for $30 \mathrm{~min}$ and then $0.25 \mathrm{ml}$ of $1 \mathrm{M}$ glycine was added to block unreacted glutaraldehyde incubating an additional $30 \mathrm{~min}$ before dialysis. PeptideKLH conjugate $(200 \mu \mathrm{g})$ emulsified with Freund's complete adjuvant was injected in rabbit lymphatic drainage areas. Every 4 weeks, rabbits were boosted with the same antigen emulsified with Freund's incomplete adjuvant. From the third boost, antigens were changed to peptide-RSA. Rabbits were bled after the fourth boost. All the antisera gave a titer between $1 / 2000$ and $1 / 5000$ on dot blots with the individual peptides. At this stage, the incubation of antisera with $400 \mu \mathrm{g} / \mathrm{ml}$ of the corresponding peptide, but not with other peptides, abolished their immunoreactivity. Antisera were further purified by affinity chromatography on immobilized antigen columns prepared by coupling free peptide antigens to activated aldehyde-agarose (Actigel A, Sterogene, Arcadia, $\mathrm{CA}$ ). The aldehyde-agarose gel was washed with 3 volumes of coupling buffer $(0.1 \mathrm{~m}$ phosphate buffer, $\mathrm{pH} 7.0)$ and a solution of $2 \mathrm{mg} / \mathrm{ml}$ of free peptide antigen per milliliter of resin was brought up to $0.1 \mathrm{M}$ sodium cyanoborohydride and agitated for $2 \mathrm{hr}$ at room temperature. The gel was then washed with 10 volumes of $1 \mathrm{M} \mathrm{NaCl}$ on a Buchner funnel followed by coupling buffer. Antisera were then pumped over columns with their corresponding immobilized peptide antigen overnight at $4{ }^{\circ} \mathrm{C}$, washed extensively, and eluted with $0.1 \mathrm{M}$ glycine buffer at $\mathrm{pH} 2.8$. The protein-containing fractions were immediately neutralized with crystalline Tris and the protein peaks pooled and used. At this stage, the staining on blots was abolished by the incubation of antibodies with 20 $\mu \mathrm{g} / \mathrm{ml}$ of the free corresponding peptide but not with other peptides, demonstrating the specificity of our antisera.

Protein blot and immunological detection of PKC. Fifty micrograms of protein (Lowry et al., 1951) in Laemmli sample buffer (Laemmli, 1970) was electrophoresed on 6.5-16\% SDS-polyacrylamide gels, blotted to nitrocellulose, blocked with PBS containing 0.1\% Tween 20 (TPBS) for $12 \mathrm{hr}$, and incubated with primary antibody (diluted as indicated in the figure legends in PBS containing 3\% BSA) for $1 \mathrm{hr}$ at $4^{\circ} \mathrm{C}$. Blots were then washed with TPBS, incubated with $0.5 \mu \mathrm{Ci} / \mathrm{ml}$ iodinatcd protein A in PBS containing 3\% BSA, and then washed and autoradiographed on Kodak X-Omat RP film at $-70^{\circ} \mathrm{C}$. Films were then developed with a Konica film developer and scanned with an LKB densitometer for quantification of the $M_{r} 80,000 \mathrm{PKC}$ band. X-ray film was exposed to blots to give bands in the OD range between 0.8 and 2.5 where the sensitivity of the film is relatively linear. The integrated OD for the $M_{r} 80,000 \mathrm{PKC}$ band was taken as the relative quantity of PKC. Values for individual AD cases were expressed as the relative value to the average of normals, set at 1 .

Immunohistochemical techniques. The immunohistochemical methods were essentially as described by Cole et al (1989). In brief, $8-\mu \mathrm{m}$ thick paraffin sections were cut from blocks from $6 \mathrm{AD}$ and 6 age- 


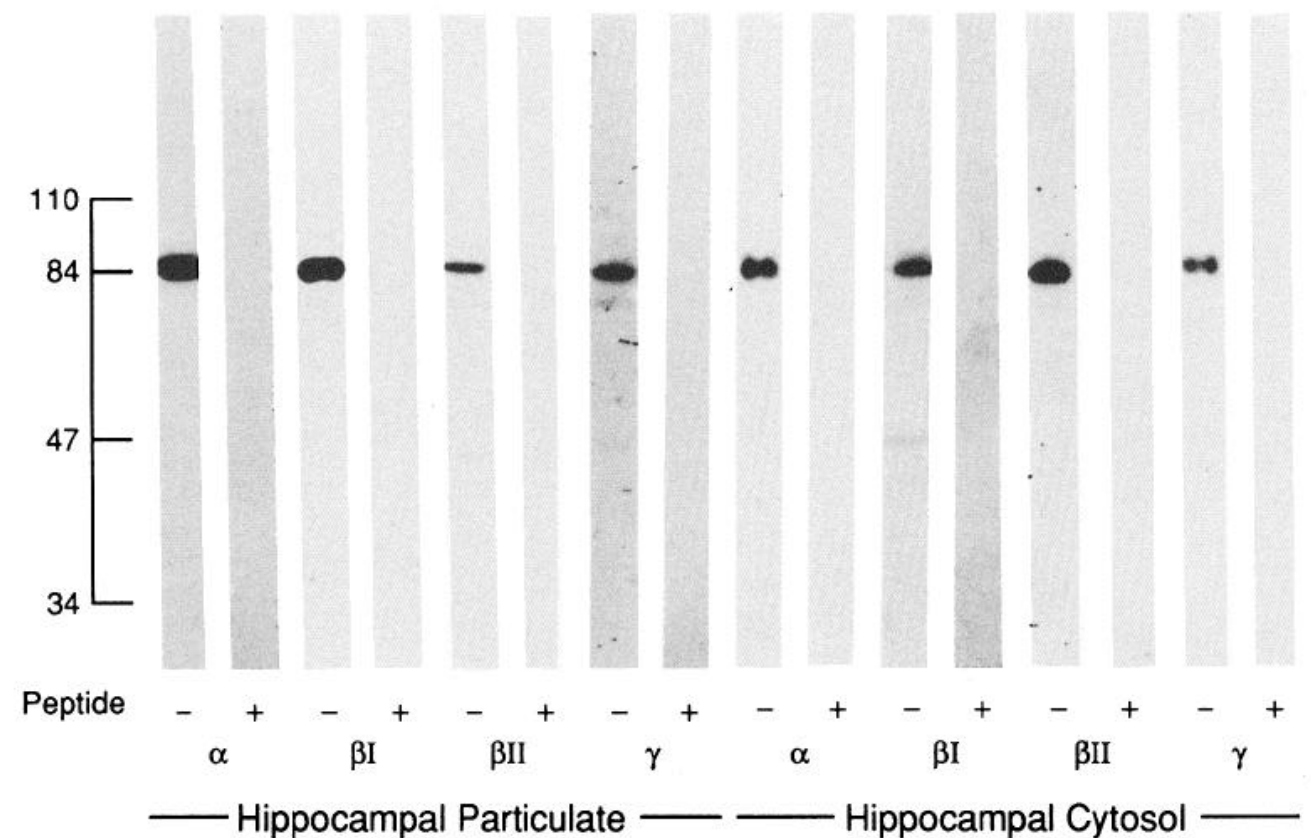

Figure 1. Specificity of antisera. Fifty micrograms of particulate fraction and $100 \mu \mathrm{g}$ of soluble fraction from hippocampal homogenate were applied to 6-16.5\% SDS-PAGE gradient gels, electrophoresed, and electroblotted to nitrocellulose. Blots were incubated with $0.1 \%$ Tween 20 -PBS, cut into strips, and incubated with the appropriate antisera to PKC (-) overnight at $4^{\circ} \mathrm{C}$. Controls $(+)$ were incubated with antisera which had been preincubated overnight with $20 \mu \mathrm{g} / \mathrm{ml}$ of free peptide prior to dilution in 3\% BSA in PBS [PKC $(\alpha)$ 1:2000; affinity-purified PKC $(\beta \mathrm{I}), 1: 100$; affinity-purified $\operatorname{PKC}(\beta \mathrm{II}), 1: 50 ; \operatorname{PKC}(\gamma), 1$ : 500]. Blots were then developed as described under Materials and Methods.

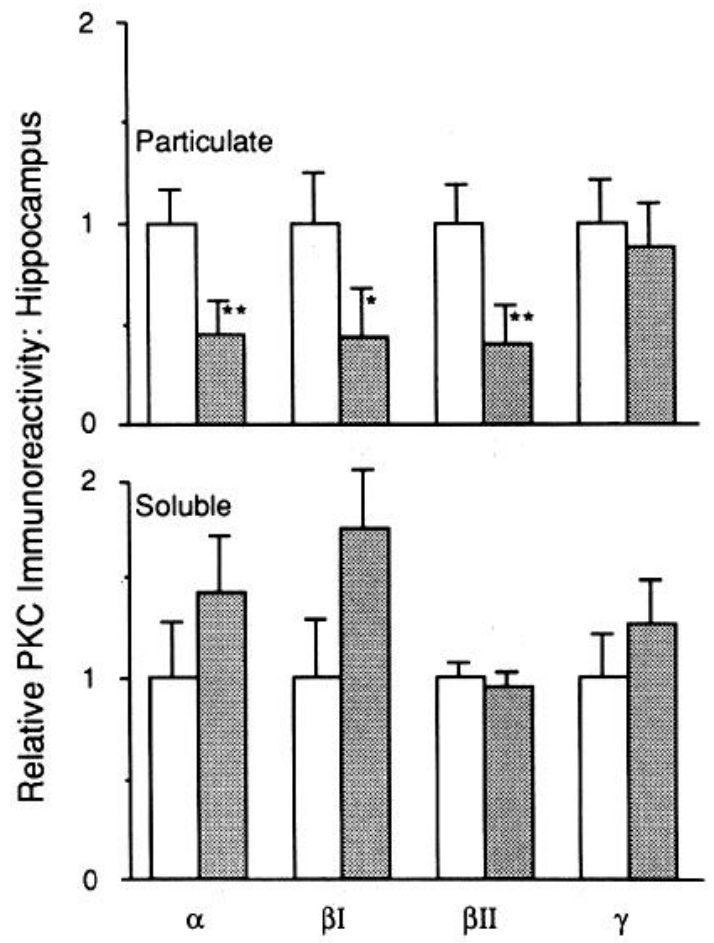

Figure 2. Immunoquantification of PKC isozymes in AD hippocampus. Fifty micrograms/lane of particulate or $100 \mu \mathrm{g} /$ lane of soluble samples from $11 \mathrm{AD}$ and 7 age-matched normal control hippocampi were electrophoresed and immunoblotted with antisera against $\operatorname{PKC}(\alpha),-(\beta \mathrm{I})$, $-(\beta \mathrm{II})$, and $-(\gamma)$ at the dilution indicated in Figure 1 . The $M, 80,000$ PKC band on autoradiographs was scanned with an LKB Ultroscan densitometer, and the relative densities from $\mathrm{AD}$ and control samples were compared by Student's $t$ test. The results depict the relative PKC isozyme immunoreactivity of AD brain samples (stippled) compared with control samples normalized to unit activity. Statistical significance: ${ }^{*} p$ $<0.05,{ }^{* *} p<0.01$. matched normal controls. Sections from midfrontal, inferior parietal and superior temporal cortex, hippocampus, nucleus basalis of Meynert $(\mathrm{NbM})$ /basal ganglia, and cerebellum were deparaffinized and incubated in $0.3 \%$ hydrogen peroxide in methanol for $30 \mathrm{~min}$, washed in TBS, $\mathrm{pH} 7.4$ (50 mM Tris-buffered saline), treated for $5 \mathrm{~min}$ in $10 \mu \mathrm{g} / \mathrm{ml}$ proteinase $\mathrm{K}$ in TE (10 mM Tris- $\mathrm{HCl}$, pH 7.4, 1 mM EDTA), and then incubated in primary antibody $(1: 100)$ in $3 \%$ goat serum or affinity-

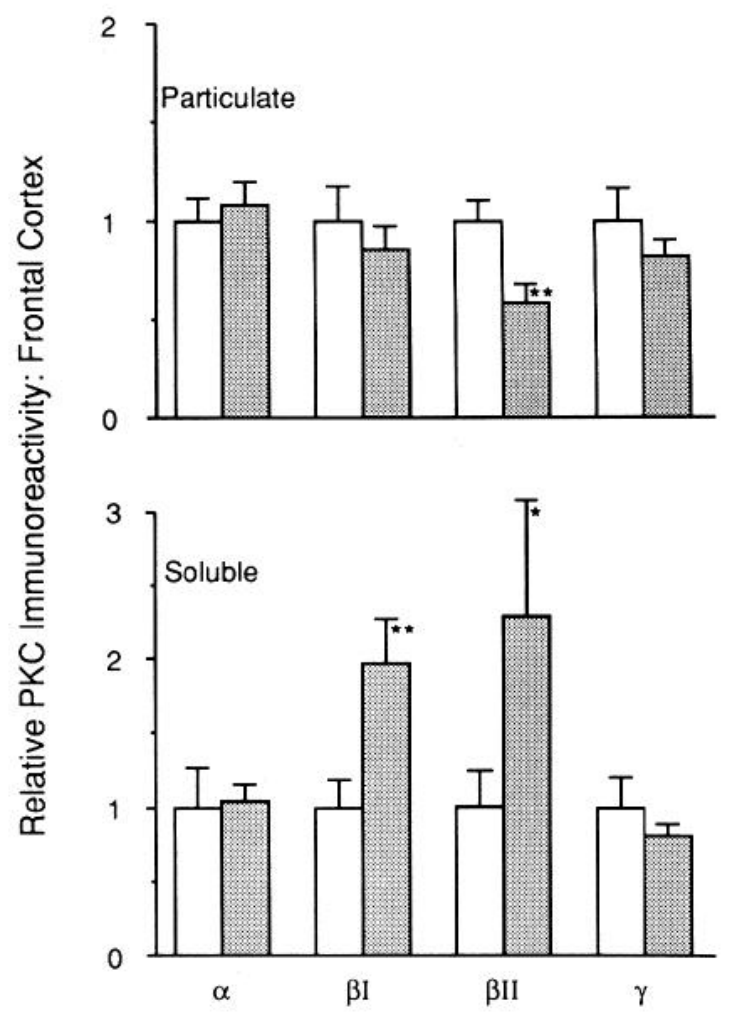

Figure 3. Immunoquantification of PKC isozymes in AD cortex. Cortical samples were analyzed as in Figure 2. 

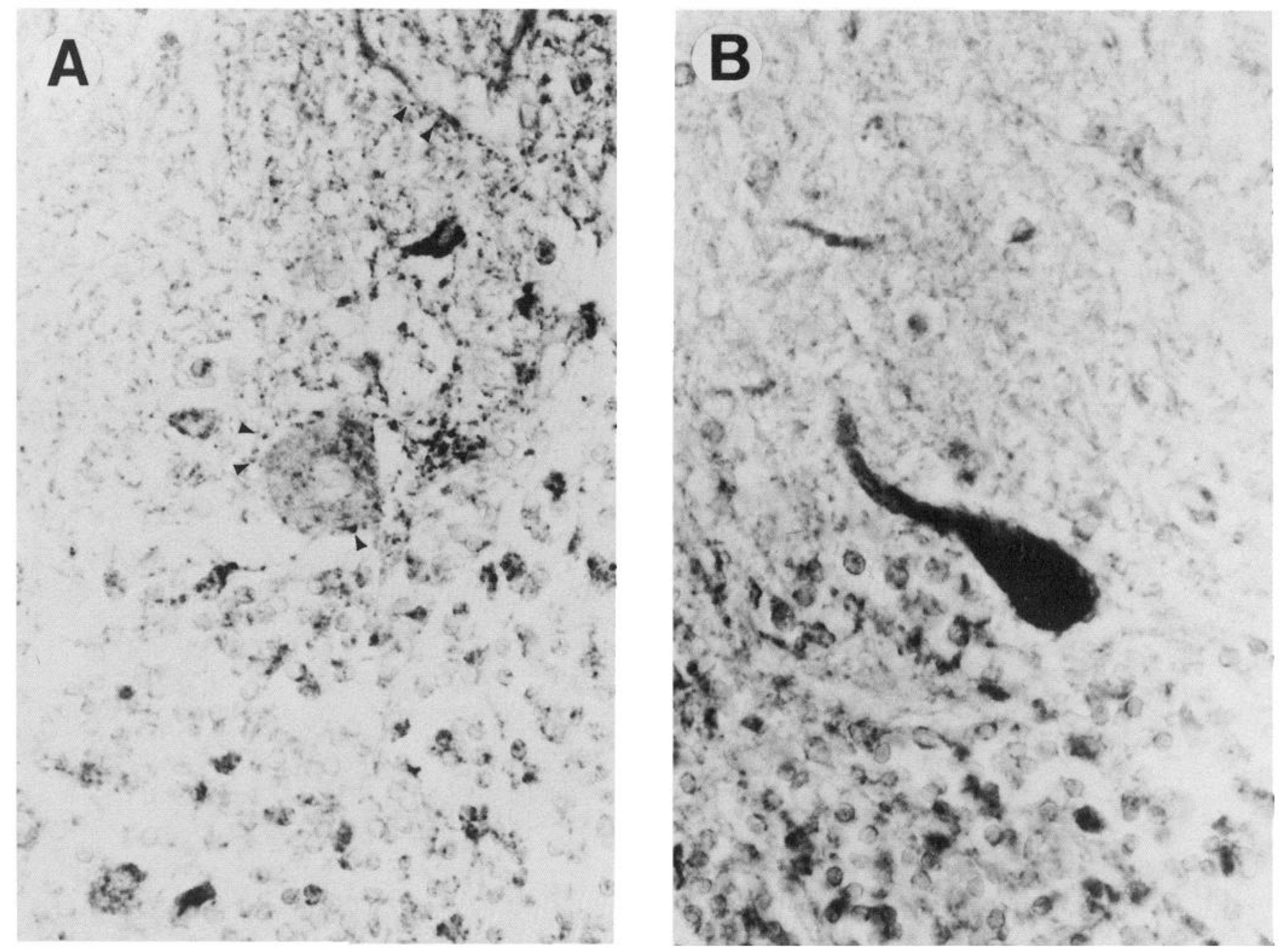

Figure 4. PKC immunoreactivity in the normal human cerebellum. $A$, Anti-PKC $(\beta \mathrm{II})$ reacted with terminals around the Purkinje cells and in the molecular layer (arrowheads). B, Anti-PKC $(\gamma)$ reacted with the Purkinje cells. $\times 300$.

purified antibody (1:20) overnight. After TBS washing and incubation with biotinylated second antibodies, sections were processed with a Vectastain ABC elite kit and developed in $0.4 \mathrm{mg} / \mathrm{ml}$ diaminobenzidine/ $100 \mathrm{~mm}$ Tris- $\mathrm{HCl}$ and $0.0135 \%$ hydrogen peroxide, $\mathrm{pH} 7.4$. Selected sections were counterstained with hematoxylin, thioflavine $\mathrm{S}$, and $\mathrm{Al}$ cian blue in $0.7 \mathrm{M} \mathrm{MgCl}_{2}$. To show the specificity of the staining, control and $\mathrm{AD}$ sections were incubated overnight with antiserum adsorbed with $400 \mu \mathrm{g} / \mathrm{ml}$ (for sera) or $20 \mu \mathrm{g} / \mathrm{ml}$ (for affinity-purified antibodies) of the corresponding free peptide and without primary antiserum; there was no staining under these conditions. The same concentration of other peptides was without effect. In addition, neocortical serial sections were immunostained with anti-ubiquitin (1:2000, courtesy of Dr. A. Haas) as previously described (Love et al., 1988), with anti-paired helical filament (PHF; 1:250, courtesy of Dr. D. Selkoe), and with anti-amyloid $\beta$-protein (1:500, courtesy of Dr. C. Masters). In case of anti- $\beta$-protein staining, sections were treated with formic acid (99\%) for $20 \mathrm{~min}$ prior to immunostaining.

Morphometry. Total cell counts in 20- $\mu$ m-thick Nissl sections were performed with a Quantimet 970 as previously described (Terry et al., $1981)$. In each adjacent section, the number of anti-PKC( $\beta$ II $)$ immunolabeled large pyramidal cells $(>90 \mu \mathrm{m})$ was counted in layers 3 and 5 of cerebral cortex in 10 fields of $1 \mathrm{~mm}^{2}$ each. Also, anti-PKC $(\beta \mathrm{II})-$ immunostained, thioflavine S-counterstained sections of the superior temporal cortex were used to determine the proportion of immunoreacting classical plaques in relation to the total number of thioflavineS-positive classical plaques.

\section{Results}

Anti-PKC immunoreactivity in homogenates of cerebral cortex and hippocampus prepared from AD patients as compared to controls

The specificities of the antisera used for the current study were tested on Western blots where total particulate proteins or total soluble proteins were electrotransferred onto nitrocellulose paper. Rabbit antibodies against C-terminal synthetic peptide of $4 \mathrm{PKC}$ isozymes $-\alpha, \beta \mathrm{I}, \beta \mathrm{II}$, and $\gamma-$ all recognized $\mathrm{PKC}$ as a $M_{r} 80,000$ protein in both particulate and soluble fractions (Fig. 1). The staining of this band was eliminated by incubation of each antibody with an excess of free peptide showing the specificity. The immunoquantification of this band in 7 control and 11 AD hippocampal particulate fractions demonstrated a significant reduction in $\mathrm{AD}$ in anti-PKC $(\alpha),-(\beta \mathrm{I})$, and $-(\beta \mathrm{II})$ immunoreactivity with a trend towards an increase in the AD cytosol (Fig. 2). There was no change in anti-PKC $(\gamma)$ staining of the $M, 80,000$ band. Anti-PKC $(\beta$ II $)$ showed a reduced staining on Western blots in the particulate fraction from frontal cortex with a concomitant increase in the soluble fraction (Fig. 3). Anti- 

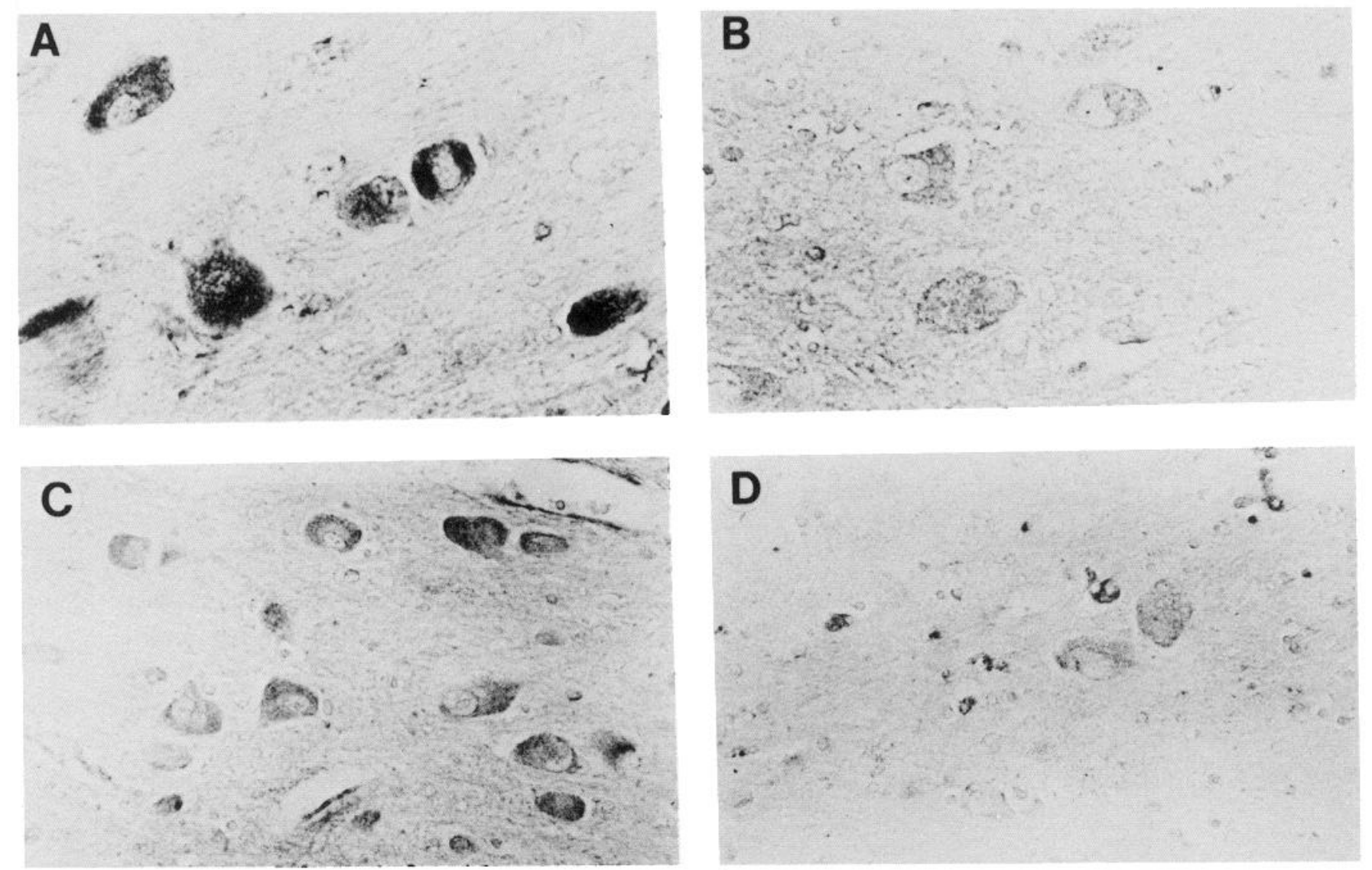

Figure 5. PKC immunoreactivity in the nucleus basalis of Meynert $(\mathrm{NbM})$. Control $(A)$ and $\mathrm{AD}(B)$ sections immunolabeled with anti-PKC $(\alpha)$; $\mathrm{AD}$ sections displayed decreased labeling. Control $(C)$ and $\mathrm{AD}(D)$ sections immunolabeled with anti-PKC $(\beta \mathrm{II}) ; \mathrm{AD}$ sections displayed a moderate decrease in labeling. $\times 250$.

PKC $(\beta \mathrm{I})$ showed an elevated staining in the soluble fraction. Anti-PKC $(\alpha)$ and $-(\gamma)$ staining were not altered in $\mathrm{AD}$ cortex.

\section{Anti-PKC staining is altered in AD brain sections}

In brain sections from normal individuals, anti-PKC antisera stained a set of neurons with a characteristic pattern for each isoform. In control cerebellar sections, anti-PKC $(\alpha)$ immunoreacted lightly with the Purkinje cells. Anti-PKC $(\beta \mathrm{I})$ moderately immunostained Purkinje cells and the internal granular cell layer. Anti-PKC $(\beta \mathrm{II})$ immunolabeled, with a granular pattern, the nerve terminals around Purkinje cell bodies (Fig. $4 A$ ) and around the dendrites in the molecular layer. Purkinje cell bodies and the internal granular layer glomerulus were lightly stained with anti-PKC $(\beta I)$. Anti-PKC $(\gamma)$ primarily labeled Purkinje cell somata (Fig. $4 B$ ). There were no detectable differences in PKC immunostaining among 6 normal and $6 \mathrm{AD}$ cerebellar sections.

Neurons within the control NbM (Fig. 5, $A, C$ ) and the supraoptic nucleus (SON) (Fig. 6, $A, C$ ) displayed intense immunostaining with anti-PKC $(\alpha)$ and $-(\beta \mathrm{II})$; in the AD NbM (Fig. $5, B, D$ ) and SON (Fig. $6, B, D$ ), a moderate to marked decrease in immunolabeling intensity was observed with anti-PKC $(\alpha)$ and $-(\beta \mathrm{II})$. A similar strong immunostaining for anti-PKC $(\alpha)$ and $-(\beta \mathrm{II})$ in $\mathrm{NbM}$ and SON was observed in all 6 normal cases and a reduced staining was observed in all $6 \mathrm{AD}$ cases.

In the control hippocampal sections, moderate immunostaining was observed with all the anti-PKC antibodies $(\alpha, \beta \mathrm{I}, \beta \mathrm{II}$, and $\gamma$ ) (Fig. 7, $A, C, E, G$ ) in the pyramidal cells of CA3 and
CA4, with less immunoreaction in CA1 and CA2. Additionally, $\operatorname{PKC}(\gamma)$ moderately immunolabeled the granular cells in the dentate gyrus. Some immunoreactivity was noted with antiPKC $(\alpha),-(\beta \mathrm{I})$, and $-(\beta \mathrm{II})$ in the wall of small vessels and glial cells. In AD hippocampal sections a modest increase in immunolabeling intensity was noted in pyramidal neurons of CA3 and CA4 with anti-PKC $(\alpha)$ and $-(\beta \mathrm{I})$ (Fig. $7, B, D)$ and a marked increase with anti-PKC $(\beta \mathrm{II})$ (Fig. $7 F)$. An increase in the immunostaining with anti-PKC $(\alpha),-(\beta \mathrm{I})$, and $-(\beta \mathrm{II})$ was noted in all 6 cases of AD sections, although we did not attempt to quantify the staining using morphometric methods because of the complex feature of the immunostaining and relatively high background staining of neuropil in both control and AD sections. The AD hippocampus displayed a relative increase in the number of $\operatorname{PKC}(\alpha)$ immunoreactive glial cells in the areas where abundant plaques were found with thioflavine $S$. No alterations in AD were noted in the PKC immunoreactivity of vessels or white matter. Anti-PKC $(\beta \mathrm{I})$ also immunostained dystrophic neurites at the peripheries of plaques (Fig. $7 D$ ) in CAl and subiculum. No significant changes were noted with anti-PKC $(\gamma)$ (Fig. 7, $G, H$ ).

In control neocortical sections, anti-PKC $(\alpha)$ and $-(\beta \mathrm{I})$ moderately stained the cytoplasm of the pyramidal cells (Fig. 8, $A$, $C$ ). Some immunoreactivity was noted in small neurons, glial cells, and small vessel walls. In AD neocortical sections, no significant changes in the patterns of pyramidal neuron immunostaining were observed with anti-PKC $(\alpha)$ and $-(\beta \mathrm{I})$ (Fig. 

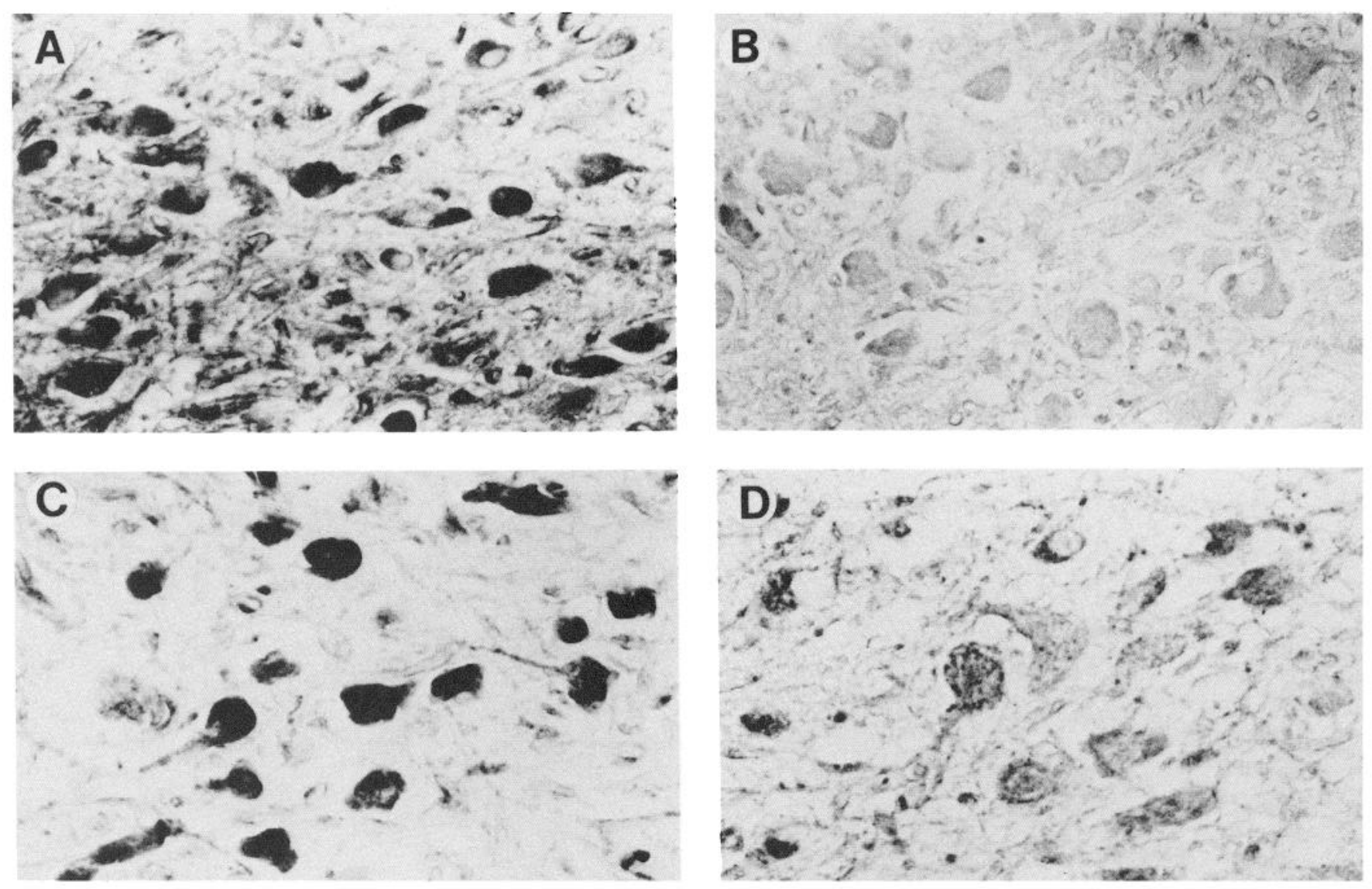

Figure 6. PKC immunoreactivity in the supraoptic nucleus (SON). Control $(A)$ and $\mathrm{AD}(B)$ sections immunolabeled with anti-PKC $(\alpha)$; $\mathrm{AD}$ sections showed decreased labeling. Control $(C)$ and $\mathrm{AD}(D)$ sections immunolabeled with anti-PKC $(\beta \mathrm{II})$; $\mathrm{AD}$ sections showed decreased labeling. $\times 250$.

$8, B, D)$. Some immunoreactivity was also noted in nuclei, neurites, small neurons, and walls of small vessels. In control cortical sections, anti-PKC $(\beta \mathrm{II})$ intensely stained about $50 \%$ of the pyramidal neurons in layers 3 and 5 (Fig. $8 E$ ). In AD cortical sections, total large neuronal populations were reduced by $50 \%$, and only $25 \%$ of the remaining neurons were immunolabeled with anti-PKC $(\beta \mathrm{II})$ (Fig. 9). That is, while total large neuron populations in layers 3 and 5 were reduced by half in AD, anti$\mathrm{PKC}(\beta \mathrm{II})$ immunoreactive large neurons were reduced by $80 \%$, and those remaining stained less intensely than the controls (Fig. $8 F)$.

In addition to neurons, glial cells, and vessels, anti-PKC immunostained neuritic plaques in AD. Anti-PKC $(\alpha)$ reacted diffusely with entire plaques and with glial cells around them (Fig. $10 A)$. Anti-PKC $(\beta I)$ stained dilated neurites in the plaques (Fig. $7 D)$. With anti-PKC $(\beta \mathrm{II})$ an intense fibrillar immunoreactivity was found in the amyloid-containing zones of plaques (Fig. $10 B)$. These were corroborated in serial sections counterstained with Alcian blue (Fig. 10C) and thioflavine S, as well as in adjacent sections immunostained with anti-amyloid $\beta$-protein (Fig. 10D), anti-ubiquitin (Fig. 10E), and anti-PHF (Fig. 10F).
About $80 \%$ of the thioflavine-S-positive classical plaques were moderately immunoreactive to anti-PKC $(\beta \mathrm{II})$ in the cores and fibrillar zones. In all cases, staining could be adsorbed out with an excess $(20 \mu \mathrm{g} / \mathrm{ml}$ peptide for affinity-purified antibody) of competing free peptide immunogens.

\section{Discussion}

Reduced PKC levels determined by radioactive phorbol ester binding in particulate fractions from $\mathrm{AD}$ cortex and a trend toward elevated PKC levels in AD soluble fractions are previously reported biochemical abnormalities in AD brain (Cole et al., 1988). PKC is a family of closely related kinases, and the individual isozymes may have distinct distributions and functions (Nishizuka, 1988, 1989), although no such information is yet available for human brains. Our previous biochemical study made no effort to differentiate isoforms of PKC. Thus, it was possible that the reported alterations in the activity, distribution, and concentration are restricted to a certain isoform of PKC. It was also unknown whether altered PKC biochemistry is restricted to certain cell types or is a general phenomenon. The current study deals with both of these uncertainties.

Figure 7. PKC immunoreactivity in the control $(A, C, E, G)$ and $\mathrm{AD}(B, D, F, H)$ hippocampus. $A$ and $B$ were stained with anti-PKC $(\alpha)$; $C$ and $D$ with anti-PKC $(\beta \mathrm{I})$, some immunoreactivity being noted in blood vessel walls (arrows) and in dystrophic neurites of plaques (arrowheads); $E$ and $F$ with anti-PKC $(\beta \mathrm{II})$, increased immunostaining being observed in the pyramidal cells of CA4-CA3 AD hippocampus; $G$ and $H$ with anti-PKC( $\gamma$ ), no differences being noted between control and AD hippocampus. $\times 268$. 

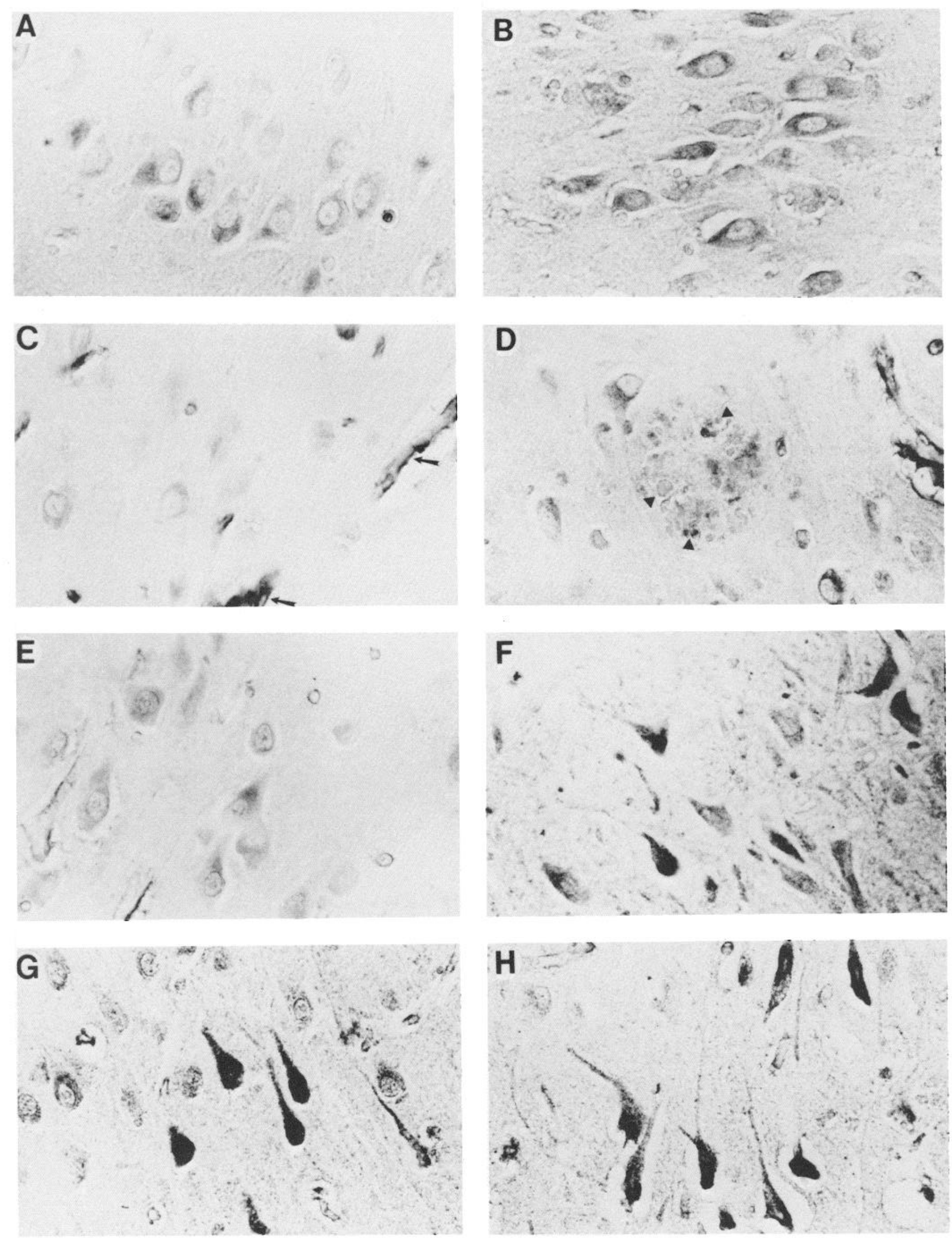

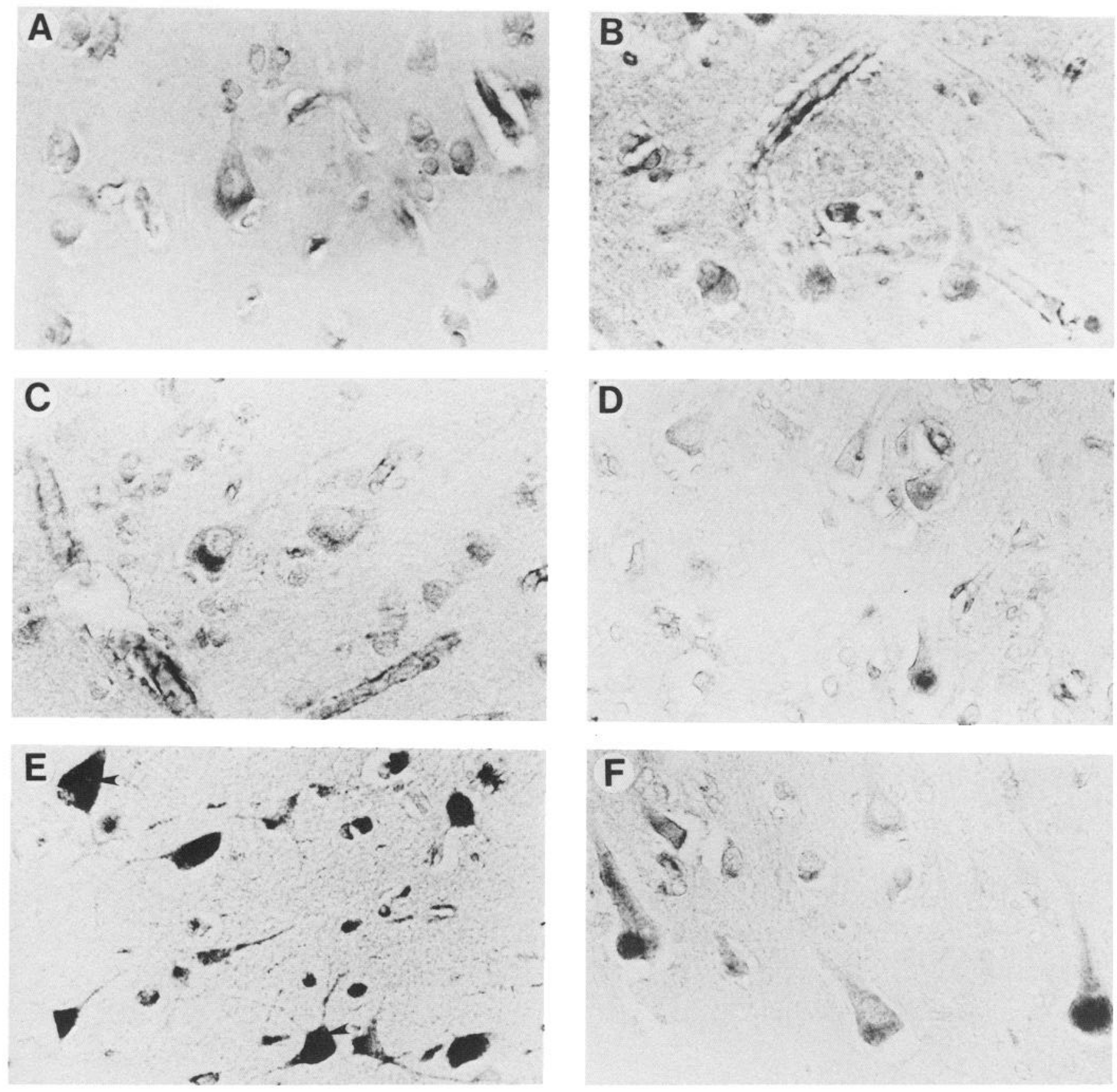

Figure 8. PKC immunoreactivity in the human neocortex. Control $(A)$ and $\mathrm{AD}(B)$ pyramidal neurons immunostained with anti-PKC $(\alpha)$; some immunolabeling of blood vessels was noted. Control $(C)$ and $\mathrm{AD}(D)$ pyramidal cells immunostained with anti-PKC $(\beta \mathrm{I})$. Control $(E)$ and $\mathrm{AD}(F)$ pyramidal neurons immunoreacted with anti-PKC $(\beta \mathrm{II})$; in this last, decreased immunostaining was observed in $\mathrm{AD}$. In the control neocortex $(E)$, some neurons display nuclear staining (arrowheads). $\times 350$.

Tissue- or cell-specific expression of PKC has been examined by several methods. First, a phorbol ester binding study demonstrated PKC is distributed unevenly in the brain (Worley et al., 1986). This method cannot distinguish multiple isozymes of PKC. Kuo and his collaborators (Girard et al., 1985; Wood et al., 1986) have shown, using polyclonal antibodies, that PKC is present mostly in presynaptic terminals and the periphery of many neuronal cell types. Using monoclonal antibodies, Mochly-Rosen and colleagues (1987) found staining of both neurons and astrocytes and related glial elements.
In cerebellum, Hidaka et al. (1988) showed the distinct distribution of $\operatorname{PKC}(\alpha),-(\beta)$, and $-(\gamma)$ isozymes in oligodendrocytes, the molecular and granular layers, and Purkinje cells, respectively. The presence of $\operatorname{PKC}(\gamma)$ in Purkinje cells and $\operatorname{PKC}(\beta)$ in granule cells has also been reported by Huang and his collaborators (1988); their anti-PKC $(\alpha)$ antibody stained both Purkinje and granule cells. A recent report by Nishizuka (1988) demonstrated the mutual exclusion of $\operatorname{PKC}(\beta \mathrm{I})$ and $-(\beta \mathrm{II})$ immunoreactivity. In their study, $\operatorname{PKC}(\beta \mathrm{I})$ was associated with granule cell bodies and $\mathrm{PKC}(\beta \mathrm{II})$ immunoreactivity surrounded 
the Purkinje cell bodies and dendrites, most likely representing the numerous nerve terminals synapsing with Purkinje cells. In situ hybridization studies by Brandt et al. (1987) and Young (1988) are consistent with the immunohistochemical results. They have shown that the transcripts of PKC $(\beta I)$ and $-(\beta I)$ isozymes localize in the granule cell layer of the cerebellar cortex, and the transcript of PKC $(\gamma)$ localizes in Purkinje cells, although no definite hybridization was detected in the cerebellar cortex with the $\operatorname{PKC}(\alpha)$ probe. In general, our results with human cerebellum are consistent with the results obtained with animal studies. There was almost no anti-PKC $(\beta I I)$ reactivity in the cytoplasm and dendrites of the Purkinje cells, although punctate staining was observed in the Purkinje cell periphery, suggesting anti-PKC $(\beta I I)$ labeled the presynaptic component or the tightly membrane-bound PKC of the postsynaptic component. Consistent with in situ hybridization studies and previous immunohistological studies in animals, the Purkinje cells were strongly labeled with anti-PKC $(\gamma)$ antibody in human cerebellum.

In the rabbit hippocampus, $\operatorname{PKC}(\alpha)$ transcripts were present in pyramidal cells and in slightly increased amounts in the CA3 pyramidal cells, cells in the hilus of the dentate gyrus, and the granule cells (Young, 1988). PKC $(\beta)$ and $-(\gamma)$ genes were expressed in the pyramidal cell layer and in the granule cells of the dentate gyrus. Excluding the brain stem and spinal cord, where some cells were labeled only by the $\mathrm{PKC}(\beta \mathrm{I})$ probe, the pattern of distribution of $\mathrm{PKC}(\beta \mathrm{I})$ and $-(\beta \mathrm{II})$ transcripts was identical in the regions studied (Brandt et al., 1987). Consistent with these in situ hybridization studies and immunohistochemical works of Huang and his collaborators (1988), both pyramidal cells of the hippocampus and granule cells of the dentate gyrus were stained by all PKC antibodies in humans. These investigators showed that $\operatorname{PKC}(\alpha)$ appeared primarily in the cytoplasm of neurons, whereas $\mathrm{PKC}(\beta \mathrm{II})$ seemed to associate with the nucleus as well. Anti-PKC $(\alpha)$ antibody labeled glia-like cells in humans, particularly in AD cases and in plaque-associated astrocytes. In vitro experiments showed the presence of PKC in cultured glia (Neary et al., 1986, 1988; Pearce et al., 1986; Murphy et al., 1988). An investigation of the PKC substrates in glial components will be needed to clarify the physiological significance of PKC in the glia system. For example, it is possible that trophic factors induced by PKC are involved in the activation of microglia. In addition, a glial protein, vimentin, is reported as a substrate of PKC (Nishizuka, 1989). Thus, it is probable that $\mathrm{PKC}(\alpha)$ in glial cells plays an important role in the response to neurodegeneration and regeneration.

The different distributions of these $4 \mathrm{PKC}$ isozymes within the human brain are consistent with the notion that the different isozymes of PKC play different roles there. None of these PKC isozymes exhibits a pattern corresponding to any single neurotransmitter system. This is consistent with the observation that multiple transmitters can stimulate inositol lipid turnover, with resultant release of diacylglycerol and activation of PKC (Nishizuka 1988, 1989). PKC is probably involved in processes that are common to multiple neuronal types.

In the neocortex, the reduction in $\mathrm{PKC}(\beta \mathrm{II})$ in $\mathrm{AD}$ was detected by both biochemical and immunohistochemical techniques. There was a general trend toward decreased particulate and increased supernatant or cytosolic immunostaining of Western blots in AD. Because roughly two-thirds of total protein was in the pellet fraction, the net effect was a decrease in PKC. The most significant changes in the cortex were the reduction in anti$\mathrm{PKC}(\beta \mathrm{II})$ immunoreactivity in the pellet and the concomitant

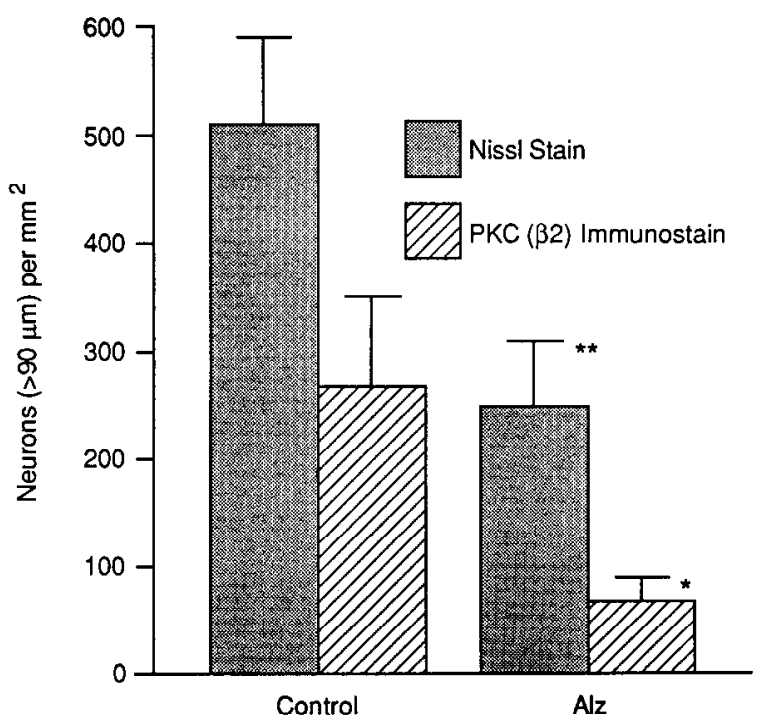

Figure 9. Reduced number of anti-PKC $(\beta \mathrm{II})$-positive neurons in cortex. Average number of anti-PKC $(\beta \mathrm{II})$-immunostained large neurons $(>90 \mu \mathrm{m})$ per $\mathrm{mm}^{2}$ in the parietal cortex and the average number of Nissl-stained large neurons in adjacent sections of the same area in 6 control and $6 \mathrm{AD}$ cases. AD samples presented an $80 \%$ decrease in the number of anti-PKC $(\beta I I)$-immunostained neurons relative to the controls $\left({ }^{* *} p<0.01\right)$. Total number of neurons are decreased $50 \%$ in AD $\left({ }^{*} p<0.02\right)$.

increase in the supernatant observed on Western blots. Consistent with these biochemical data, a significant decrease in anti$\mathrm{PKC}(\beta \mathrm{II})$ immunoreactivity was observed in $\mathrm{AD}$ cortical sections. This is attributable both to preferential loss of $\mathrm{PKC}(\beta \mathrm{H})$ immunoreactive subpopulations of large neurons and to reduced PKC $(\beta$ II $)$ content of those remaining. The cerebral cortex has very high $\mathrm{PKC}(\beta \mathrm{II})$ levels, which account for the majority of PKC (Ase et al., 1988), suggesting that changes in $\mathrm{PKC}(\beta \mathrm{II})$ largely account for the reduced PKC activity and amount in the pellet fractions and the trend toward higher cytosolic $\mathrm{PKC}$ which we previously reported in the AD cortex (Cole et al., 1988).

The immunohistochemical results in the hippocampus were less straightforward since they showed an increase in $\operatorname{PKC}(\alpha)$, $-(\beta \mathrm{I})$, and $-(\beta \mathrm{II})$ isoform staining despite the significant decrease seen with Western blots of the particulate fraction. This discrepancy may result from the fact that PKC-immunoreactive neuronal soma examined in sections represent only a small fraction of the tissue examined by Western blot analysis, which averages the neuronal soma with glial, vascular, and, perhaps most importantly, synaptic or neuropil contributions to enzyme levels. Recent results indicate a synaptic localization for the different PKC isoforms (Ase et al., 1988; Huang et al., 1988; Kose et al., 1988). Because in AD brain the synaptic mass is dccreased (Masliah ct al., 1989), the reduced PKC concentration on Western blot may be due mainly to loss of synaptic volume. Curiously, the increased PKC $(\beta \mathrm{II})$ immunostaining affected only the pyramidal cell layer neurons in $\mathrm{CA} 4-\mathrm{CA} 2$, while those in CA1 showed only the same faint positivity seen in control hippocampus. Why pyramidal neurons from CA4-CA2 (a region comparatively less involved with $\mathrm{AD}$ pathology) should show increased staining while those in CAl (a region of selective vulnerability in AD) were unaffected is unknown at present. The changes in $\mathrm{PKC}(\alpha),-(\beta \mathrm{I})$, and $-(\beta \mathrm{II})$ in the hippocampus may 

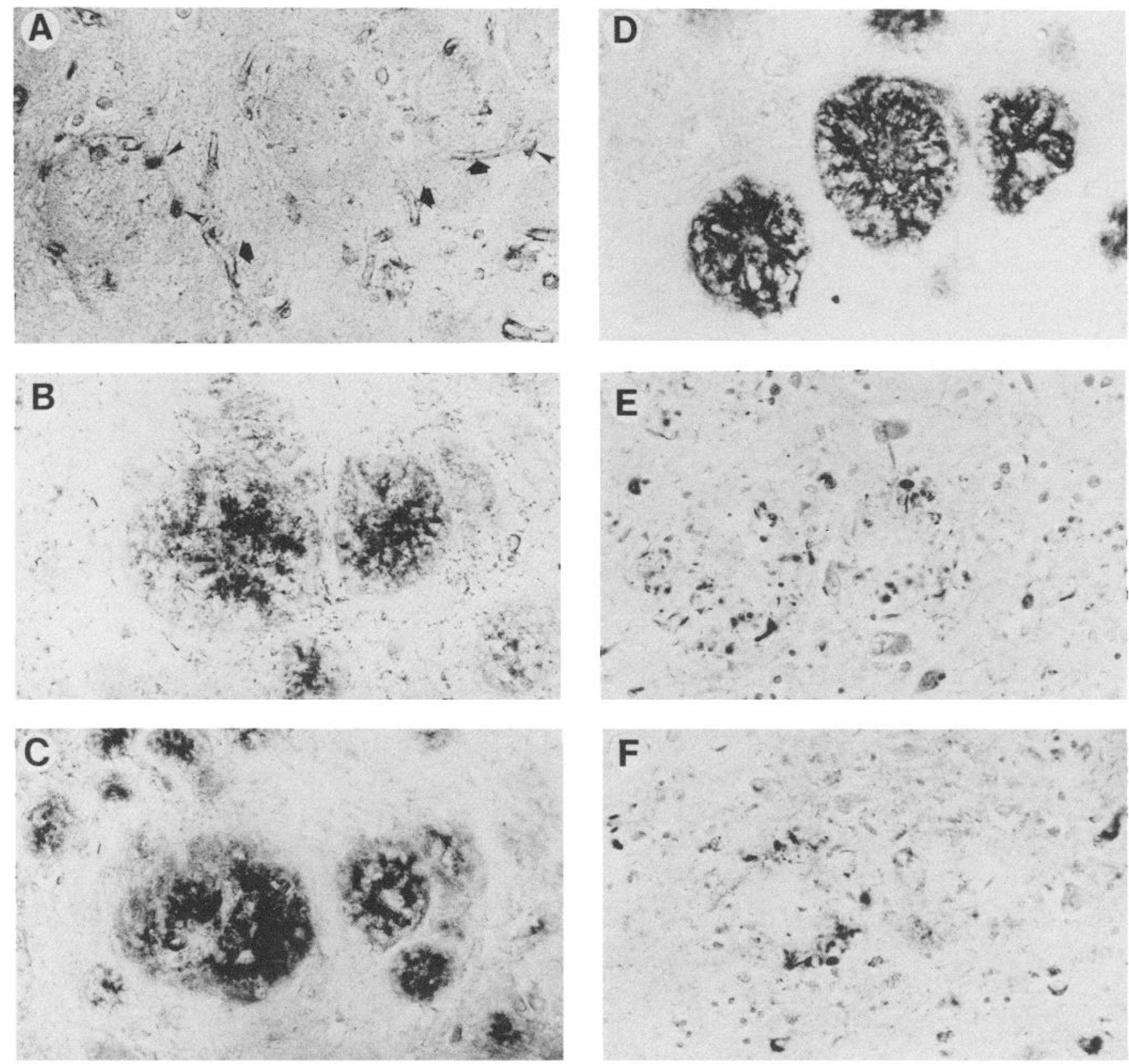

Figure 10. Comparative morphology of plaques in serial sections. A, Anti-PKC $(\alpha)$ where arrowheads indicate glial cells around the plaques. Some vessels (arrows) are also stained; $B$, anti-PKC $(\beta \mathrm{II}) ; C$, anti-PKC $(\beta \mathrm{II})$ counterstained with Alcian blue; $D$, anti-amyloid $\beta$-protein $(11-22) ; E$, antiubiquitin; and $F$, anti-PHF. $\times 304$.

reflect an involvement of this region in $\mathrm{AD}$ and particularly in the memory deficits underlying the dementia because PKC appears to play a vital role in establishing long-term potentiation, believed to be a cellular substrate for memory (Routtenberg, 1986). In 2 other regions of selective vulnerability in $\mathrm{AD}, \mathrm{NbM}$ and SON, anti-PKC $(\alpha)$ and $-(\beta I I)$ immunoreactivity was drastically reduced. It is possible, although speculative, that increased PKC staining in certain neurons is the reflection of compensatory mechanisms which allow the neurons to survive yet unknown insult in AD.

In $\mathrm{AD}$ brains, there are 2 prominent pathological lesions, neuritic plaques and neurofibrillary tangles. Various components of neuritic plaques immunostain with anti-PKC antibod- ies (Fig. 11), whereas tangles do not. The PKC( $\beta$ II) antibody mainly immunolabels material colocalized with amyloid in the plaques. This labeling is adsorbed out by peptide. Anti-PKC $(\beta I \mathrm{II})$ staining of plaques does not resemble $\alpha_{1}$-antichymotrypsin staining but is, instead, similar to anti-amyloid- $\beta$-protein staining (Fig. 10). The material stained with anti-PKC ( $\beta \mathrm{II})$ is neither stained with anti-PKC $(\alpha)$ nor - $(\beta I)$ but is stained with goat antiPKC serum prepared against total PKC (Huang and Huang, $1986)$ and with monoclonal antibody against $P K C(\beta)$ which does not differentiate $\beta \mathrm{II}$ from $\beta \mathrm{I}$ (unpublished observations). It is therefore likely that amyloid staining of neuritic plaques with anti-PKC $(\beta \mathrm{II})$ serum is specific and is not merely the result of IgG adsorption or the presence of a cross-reacting epitope. PKC 


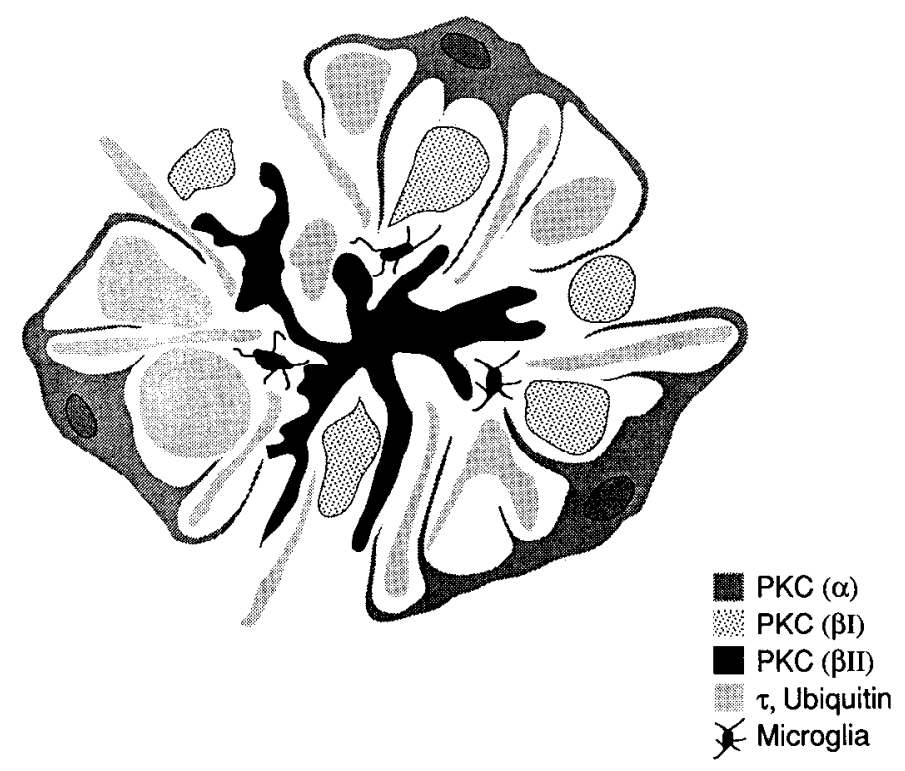

Figure 11. Schematic presentation of neuritic plaque staining with anti-PKC antibodies. Core portion of neuritic plaques occupied by amyloid was strongly stained with anti-PKC $(\beta$ II $)$. Spheric neurites are strongly stained with anti-PKC $(\beta I)$. Fusiform neurites are intensely stained with anti-PHF, although they were negative with any of our anti-PKC antibodies. Astrocytic fibers are stained with anti-PKC $(\alpha)$.

has been shown to phosphorylate amyloid precursor protein in vitro (Gandy et al., 1988), indicating a hypothetical connection between $\mathrm{PKC}$ and amyloid precursor processing. $\mathrm{PKC}(\beta \mathrm{II})$ is found in presynaptic nerve endings (Ase et al., 1988) and in the Golgi apparatus, where it may be involved in protein processing (Nishizuka, 1989). We are currently investigating the relationship bctween amyloid and $\mathrm{PKC}(\beta \mathrm{II})$ at the ultrastructural level to get insight into the mechanisms by which $\mathrm{PKC}(\beta \mathrm{II})$ may be involved in amyloidogenesis.

Interestingly, the neuritic component of plaques was stained with anti-PKC $(\beta \mathrm{I})$ antiserum, but not with antisera against PKC $(\alpha)$, $-(\beta \mathrm{II})$, or $-(\gamma)$. The component stained with anti-PKC $(\beta \mathrm{I})$ in the plaques is distinct from fibrous glia, although the same antisera stained reactive glial cells. We have observed similar anti-PKC $(\alpha)$ and $-(\beta I)$ staining of reactive glia with experimental lesions in the rat hippocampus (Shimohama et al., 1988). The antiserum against the $\operatorname{PKC}(\gamma)$ isoform was negative with glia. No anti-PKC antisera stained neurofibrillary tangles, in contrast to anti-casein kinase II (Iimoto et al., 1990).

In conclusion, we present evidence for alterations of PKC isoenzymes in $\mathrm{AD}$. Although the cause of these alterations remains unknown, they do not simply reflect the neuropathology of $\Lambda \mathrm{D}$ since we have found similar PKC deficits in AD fibroblasts (Huynh et al., 1989). However, PKC is not simply a systemic alteration in $\mathrm{AD}$ because $\mathrm{PKC}$ alterations were not obvious in AD cerebellum and PKC alterations were drastically different from one area of the brain to another. The changes in immunohistological staining observed in AD tissue sections and with homogenates on blots may reflect, in part, reduced activation and diminished translocation of $P K C$ in $A D$, which could be directly related to neuronal dysfunction. In the rat, similar changes in PKC activity occur with age (Friedman and Wang, 1989), which suggests that a genetic defect affecting PKC could aggravate normal aging changes. The aberrant $\mathrm{PKC}$ behavior reported here should be explored further in hopes of identifying an underlying cause for neuronal dysfunction and death in AD.

\section{References}

Ase K, Saito N, Shearman MS, Kikkawa U, Ono Y, Igarashi K, Tanaka C, Nishizuka Y (1988) Distinct cellular expression of $\beta \mathrm{I}$ - and $\beta \mathrm{II}-$ subspecies of protein kinase $C$ in rat cerehellum. J Neurosci 8:38503856 .

Brandt SJ, Niedel JE, Bell RM, Young WS III (1987) Distinct patterns of expression of different protein kinase $\mathrm{C}$ mRN $\Lambda$ s in rat tissues. Cell 49:57-63.

Cole G, Dobkins KR, Hansen LA, Terry RD, Saitoh T (1988) Decreased levels of protein kinase $C$ in Alzheimer brain. Brain Res 452: $165-170$

Cole G, Masliah E, Huynh TV, DeTeresa RD, Terry R, Okuda C, Saitoh $T$ (1989) An antiserum against amyloid $\beta$-protein precursor detects a unique peptide in Alzheimer brain. Neurosci Lett 100:340-346.

Friedman E, Wang HY (1989) Effect of age on brain cortical protein kinase $\mathrm{C}$ and its mediation of 5-hydroxytryptamine release. J Neurochem 52:187-192.

Gandy S, Czernik AN, Greengard P (1988) Phosphorylation of Alzheimer disease amyloid precursor peptide by protein kinase $\mathrm{C}$ and $\mathrm{CA}^{2+} /$ calmodulin-dependent protein kinase II. Proc Natl Acad Sci USA 85:6218-6621.

Girard PR, Mazzei GJ, Wood JG, Kuo JF (1985) Polyclonal antibodies to phospholipid $/ \mathrm{Ca}^{+}$dependent protein kinase and immunocytochemical localization of the enzyme in rat brain. Proc Natl Acad Sci USA 82:3030-3034.

Green N, Alexander H, Olson A, Alexander S, Shinnick TM, Sutcliffe $J G$, Lerner RA (1982) Immunogenic structure of the influenza virus hemagglutinin. Cell 28:477-487.

Hama T, Huang K-P, Guroff G (1986) Protein kinase C as a component of a nerve growth factor-sensitive phosphorylation system in PC12 cells. Proc Natl Acad Sci USA 83:2353-2357.

Hidaka $H$, Tanaka $T$, Onoda $K$, Hagiwara $M$, Watanabe $M$, Ohta $H$, Ito Y, Tsurudome M, Yoshida T (1988) Cell type-specific expression of protein kinase $\mathrm{C}$ isozymes in the rabbit cerebellum. $\mathbf{J}$ Biol Chem 263:4523-4526.

Huang K-P, Huang FL (1986) Conversion of protein kinase C from a $\mathrm{Ca}^{2+}$-dependent to an independent form of phorbol ester-binding protein by digestion with trypsin. Biochem Biophys Res Commun 139:320-326.

Huang FL, Yoshida Y, Nakabayashi H, Knopf HL, Young WS III, Huang K-P (1987) Differential distribution of protein kinase C isozymes in the various regions of brain. J Biol Chem 262:15714-15720.

Huang FL, Yoshida Y, Nakabayashi H, Young WS, Huang K-P (1988) Immunocytochemical localization of protein kinase $\mathrm{C}$ isozymes in rat brain. J Neurosci 8:4734-4744.

Huynh TV, Cole G, Katzman R, Huang K-P, Saitoh T (1989) Reduced PK-C immunoreactivity and altered protein phosphorylation in Alzheimer's disease fibroblasts. Arch Neurol 43:1195-1199.

Iimoto DS, Masliah E, DeTcresa R, Tcrry RD, Saitoh T (1990) Aberrant casein kinase II in Alzheimer's disease. Brain Res 507:273-280.

Jaken S, Kiley SC (1987) Purification and characterization of three lypes of protein kinase $C$ from rabbit brain cytosol. Proc Natl Acad Sci USA 84:4418-4422.

Katzman R (1986) Alzheimer's disease. N Engl J Med 314:964-973.

Kose A, Saito N, Ito H, Kikkawa U, Nishizuka Y, Tanaka C (1988) Electron microscope localization of type I protein kinase $\mathrm{C}$ in rat Purkinje cells. J Neurosci 8:4262-4268.

Laemmli UK (1970) Cleavage of structural proteins during the assembly of the head of bacteriophage T4. Nature 227:680-685.

I owry OH, Rosebrough NJ, Farr AL, Randall RJ (1951) Protein measurement with the Folin phenol reagent. J Biol Chem 193:265275.

Love S, Saitoh T, Quijada S, Cole GM, Terry RD (1988) Alz-50, ubiquitin and tau immunoreactivity of neurofibrillary tangles, Pick bodies and Lewy bodies. J Neuropathol Exp Neurol 47:393-405.

Masliah E, Terry RD, DeTeresa RM (1989) Immunohistochemical quantification of the synapse-related protein synaptophysin in Alzheimer disease. Neurosci Lett 103:234-239.

Mochly-Rosen D, Asbaum AI, Koshland DE Jr (1987) Distinct cellular and regional localization of immunoreactive protein kinase $\mathrm{C}$ in rat brain. Proc Natl Acad Sci USA 84:4660-4664. 
Montz HPM, Davis GE, Skaper SD, Manthorpe M, Varon S (1985) Tumor promoting phorbol diester mimics two distinct neuronotrophic factors. Dev Brain Res 23:150-154.

Murphy JA, Chapman JA, Suckling AJ, Rumsby MG (1988) Protein kinase $\mathrm{C}$ activity in soluble fractions from glial cells in primary culture and subcultures. Neurosci Lett 85:255-260.

Neary JT, Norenberg LOB, Norenberg MD (1986) Calcium-activated, phospholipid-dependent protein kinase and protein substrates in primary cultures of astrocytes. Brain Res 385:420-424.

Neary JT, Norenberg LOB, Norenberg MD (1988) Protein kinase C in primary astrocyte cultures: cytoplasmic localization and translocation by a phorbol ester. J Neurochem 50:1179-1184.

Nishizuka Y (1988) The molecular heterogeneity of protein kinase C and its implications for cellular regulation. Nature 334:661-665.

Nishizuka Y (1989) Studies and prospectives of the protein kinase C family for cellular regulation. Cancer 63:1892-1903.

Ono Y, Fujii T, Ogita K, Kikkawa U, Igarashi K, Nishizuka Y (1988) The structure, expression, and properties of additional members of the protein kinase C family. J Biol Chem 263:6927-6932.

Pearce B, Morrow C, Murphy S (1986) Receptor-mcdiated inositol phospholipid hydrolysis in astrocytes. Eur J Pharmacol 121:231-243.

Routtenberg A (1986) Synaptic plasticity and protein kinase C. Prog Brain Res 69:411-435.

Sekiguchi K, Tsukuda M, Ogita K, Kikkawa U, Nishizuka Y (1987) Three distinct forms of rat brain protein kinase $\mathrm{C}$ : differential response to unsaturated fatty acids. Biochem Biophys Res Commun 145:797802 .
Shearman MS, Naor Z, Kikkawa U, Nishizuka Y (1987) Differential expression of multiple protein kinase $\mathrm{C}$ subspecies in rat central nervous tissue. Biochem Biophys Res Commun 147:911-919.

Shimohama S, Saitoh T, Gage FH (1988) Protein kinase C in hippocampus and septum following fimbria-fornix transection. Soc Neurosci Abstr 14:19.

Takai Y, Kishimoto A, Inoue M, Nishizuka Y (1977) Studies on a cyclic nucleotide-independent protein kinase and its proenzyme in mammalian tissues. I. Purification and characterization of an active enzyme from bovine cerebellum. J Biol Chem 252:7603-7609.

Terry RD, Peck A, DeTeresa R, Schechter R, Horoupian DS (1981) Some morphometric aspects of the brain in senile dementia of the Alzheimer type. Ann Neurol 10:184-192.

Wood JG, Girard PR, Mazzei GJ, Kuo JF (1986) Immunocytochemical localization of protein kinase $\mathrm{C}$ in identified neuronal compartments of rat brain. J Neurosci 6:2571-2577

Woodgett JR, Hunter T (1987) Isolation and characterization of two distinct forms of protein kinase C. J Biol Chem 262:4836-4843.

Worley PF, Baraban JM, Snyder SH (1986) Heterogeneous localization of protein kinase $C$ in rat brain: autoradiographic analysis of phorbol ester receptor binding. J Neurosci 6:199-207.

Young WS III (1988) Expression of three (and a putative four) protein kinase $C$ genes in brains of rat and rabbil. J Chem Neuroanat 1:177194. 